\title{
PENGARUH RETURN ON EQUITY RATIO DAN DEBT EQUITY RATIO TERHADAP PRICE EARNING RATIO PADA PERUSAHAAN ROKOK YANG TERDAFTAR DI BURSA EFEK INDONESIA PERIODE 2012-2016
}

\author{
${ }^{1 *}$ Arif Hidayat, ${ }^{2}$ Agus Suhartono, ${ }^{3}$ Sari Karmiyati \\ Universitas Pamulang, Tangerang Selatan, Banten, Indonesia \\ *dosen02519@unpam.ac.id
}

\begin{abstract}
Abstrak
Penelitian ini bertujuan untuk mengetahui pengaruh Return On Equity Ratio dan Debt Equity Ratio terhadap Price Earning Ratio pada Perusahaan Rokok Yang Terdaftar Di Bursa Efek Indonesia Periode 2012-2016. Metode yang digunakan adalah explanatory research dengan teknik analisis menggunakan analisis statistik dengan pengujian regresi, korelasi, determinasi dan uji hipotesis. Hasil penelitian ini Return On Equity Ratio berpengaruh signifikan terhadap Price Earning Ratio sebesar 43,2\%, uji hipotesis diperoleh signifikansi (Sig.) 0,002<0,05. Debt Equity Ratio tidak berpengaruh signifikan terhadap Price Earning Ratio sebesar 00,1\%, uji hipotesis diperoleh signifikansi (Sig.) 0,991 > 0,05. Return On Equity Ratio dan Debt Equity Ratio secara simultan berpengaruh signifikan terhadap Price Earning Ratio dengan persamaan regresi $Y=14,324+23,699 \mathrm{X} 1+-2,020 \mathrm{X} 2$ dan kontribusi pengaruh sebesar 59,6\%, uji hipotesis diperoleh Signifikansi (Sig.) 0,000<0,05.
\end{abstract}

Kata Kunci: Return On Equity Ratio, Debt Equity Ratio, Price Earning Ratio.

\begin{abstract}
This study aims to determine the effect of Return On Equity Ratio and Debt Equity Ratio on Price Earning Ratio in Cigarette Companies Listed on the Indonesia Stock Exchange for the period 2012-2016. The method used is explanatory research with analytical techniques using statistical analysis with regression, correlation, determination and hypothesis testing. The results of this study Return On Equity Ratio has a significant effect on Price Earning Ratio of 43.2\%, hypothesis testing obtained significance (Sig.) $0.002<0.05$. The Debt Equity Ratio has no significant effect on the Price Earning Ratio of 00.1\%, hypothesis testing is obtained with a significance of (Sig.) $0.991>0.05$. Return On Equity Ratio and Debt Equity Ratio simultaneously have a significant effect on Price Earning Ratio with the regression equation $Y=14,324+23.699 X 1+-2,020 X 2$ and the contribution of the influence is 59.6\%, hypothesis testing is obtained Significance (Sig.) 0.000 $<0,05$.
\end{abstract}

Keywords: Return On Equity Ratio, Debt Equity Ratio, Price Earning Ratio.

\section{PENDAHULUAN}

Bursa Efek Indonesia atau pasar modal berfungsi untuk menghubungkan para investor, perusahaan-perusahaan, dan institusi pemerintah melalui perdagangan instrument keuangan jangka panjang, dan salah satu instrument yang diperdagangkan adalah saham. Perkembangan pasar modal di Indonesia mendorong perusahaan untuk menjual sahamnya kepada masyarakat (go public) sehingga makin banyak perusahaan tercatat di bursa efek Indonesia. Setiap tahun perusahaan go public yang terdaftar di bursa efek Indonesia berkewajiban menyampaikan laporan keuangannya, karena informasi laporan keuangan merupakan unsur penting bagi investor dan para pelaku bisnis untuk keperluan analisis dan pengambilan keputusan.
Laporan keuangan melaporkan apa yang sebenarnya terjadi pada aset, laba, dan dividen selama periode tertentu. Di setiap peristiwa, informasi yang terkandung dalam sebuah laporan keuangan akan digunakan oleh para investor untuk membantunya membuat ekspektasi tentang laba dan dividen di masa mendatang (Munawir, 2008: 8-9). Salah satu alat seleksi dan analisis sahamsaham yang akan dibeli investor dapat menggunakan analisis rasio keuangan. Analisis rasio keuangan didasarkan pada keuangan historis dengan tujuan untuk memberikan indikasi kinerja keuangan dimasa datang serta memprediksi kelangsungan usaha bisnis.

Analisis laporan keuangan sangat dibutuhkan para analis dan investor guna mengambil kebijakan investasi. Salah satu 
alat analisis yang diperlukan adalah analisis fundamental, yang mencoba memperkirakan harga saham dimasa yang akan datang dengan mengestimasi nilai faktor-faktor fundamental yang mempengaruhi harga saham di masa yang akan datang. Dalam analisis fundamental, salah satu penilaian saham dilakukan dengan pendekatan Price Earning Ratio (PER) yaitu ratio antara harga pasar saham dengan laba per lembar saham. Setiap pergerakan harga saham akan mengakibatkan perubahan PER. Dan dalam penelitian ini analisis rasio keuangan yang digunakan adalah PER (Price Earning Ratio), analisis ini membandingkan antara harga pasar saham sekarang dengan laba per lembar saham. PER (Price Earning Ratio) merupakan rasio keuangan yang paling banyak digunakan investor untuk menentukan apakah investasi saham menguntungkan atau tidak, karena PER (Price Earning Ratio), merupakan salah satu alat untuk mengukur kinerja perusahaan serta dapat mempengaruhi kenaikan atau penurunan harga pasar saham perusahaan. Para investor tertarik dengan PER (Price Earning Ratio), tinggi karena akan memberikan keuntungan atas kenaikan harga pasar saham serta memcerminkan kinerja perusahaan yang baik.

Faktor yang mempengaruhi Price to Earning Ratio salah satunya adalah Rasio profitabilitas yang dalam penelitian ini

Tabel 1. Perhitungan Return On Equity, Debt to Equity Ratio dan Price to Earning Ratio Pada

Perusahaan Rokok yang terdaftar di Bursa Efek Indonesia (BEI) (Periode 2012-2016)

\begin{tabular}{|c|c|c|c|c|}
\hline Perusahaan & Tahun & ROE & DER & PER \\
\hline \multirow{5}{*}{ PT Gudang Garam Tbk } & 2012 & 2012 & 0.15 & 0.56 \\
\hline & 2013 & 2013 & 0.15 & 0.73 \\
\hline & 2014 & 2014 & 0.16 & 0.75 \\
\hline & 2015 & 2015 & 0.17 & 0.67 \\
\hline & 2016 & 2016 & 0.17 & 0.59 \\
\hline \multirow{5}{*}{ PT Hanjaya Mandala Sampoerna, Tbk } & 2012 & 2012 & 075 & 097 \\
\hline & $\frac{2012}{2013}$ & $\frac{2012}{2013}$ & $\begin{array}{l}0.15 \\
0.76\end{array}$ & 0.91 \\
\hline & 2014 & 2014 & 0.75 & 1.1 \\
\hline & 2015 & 2015 & 0.32 & 0.19 \\
\hline & 2016 & 2016 & 0.37 & 0.24 \\
\hline \multirow{5}{*}{$\begin{array}{c}\text { PT Bentoel Internasional Investama, } \\
\text { Tbk }\end{array}$} & 2012 & -0.17 & 2.6 & -12.99 \\
\hline & 2013 & -0.18 & 9.47 & -3.96 \\
\hline & 2014 & -1.63 & -8.34 & -1.65 \\
\hline & 2015 & -0.52 & -5.02 & 2.26 \\
\hline & 2016 & -0.22 & 0.43 & 8.49 \\
\hline PT Wismilak Inti Makmur, Tbk & 2012 & 0.12 & 0.84 & 20.64 \\
\hline
\end{tabular}




\begin{tabular}{|c|c|c|c|c|}
\hline \multirow{5}{*}{} & 2013 & 0.17 & 0.57 & 10.63 \\
\cline { 2 - 5 } & 2014 & 0.13 & 0.56 & 11.68 \\
\cline { 2 - 5 } & 2015 & 0.14 & 0.42 & 6.9 \\
\cline { 2 - 5 } & 2016 & 0.11 & 0.37 & 8.7 \\
\hline
\end{tabular}

Sumber: Laporan Tahunan Pada Perusahaan Rokok yang terdaftar di Bursa Efek Indonesia (BEI) periode 2012-2016

Berdasarkan Tabel di atas terlihat bahwa terjadi fluktuasi pada variabel ROE dan variabel DER. Sehingga pada variabel PER terdapat penurunan dan kenaikan pula. Dan pada peneliti sebelumnya terdapat ketidak konsistenan pengaruh pada masing-masing variabel.

Berdasarkan uraian latar belakang di atas, maka penulis tertarik pembuat penelitian dengan judul sebagai berikut "Pengaruh Return On Equity Ratio Dan Debt Equity Ratio Terhadap Price Earning Ratio Pada Perusahaan Rokok Yang Terdaftar Di Bursa Efek Indonesia Periode 2012-2016"

\section{TINJAUAN PUSTAKA}

\section{Return On Equity Ratio}

Menurut Agus Sartono (2010:124)

"Return on equity, mengukur kemampuan perusahaan memperoleh laba yang tersedia bagi pemegang saham perusahaan. Rasio ini juga dipengaruhi oleh besar kecilnya utang perusahaan, apabila proporsi utang makin besar maka rasio ini juga akan makin besar." Secara umum tentu saja semakin tinggi return atau penghasilan yang diperoleh semakin baik kedudukan pemilik perusahaan. Return On Equity dihitung sebagai berikut:

$$
\text { ROE }=\frac{\text { LABA BERSIH SETELAH PAJAK }}{\text { TOTAL EKUITAS }}
$$

\section{Debt Equity Ratio}

Rasio ini menunjukkan kemampuan perusahaan untuk memenuhi semua total kewajibannya dengan menggunakan modal sendiri. Rasio solvabilitas atau rasio utang menunjukkan kemampuan perusahaan untuk memenuhi segala kewajiban finansiilnya apabila sekiranya perusahaan tersebut pada saat itu dilikuidasi (Bambang, 2010:32). Pengukuran tingkat utang biasanya menggunakan debt ratio, debt to equity ratio, semakin tinggi rasio ini maka semakin besar pula jumlah utang yang digunakan dalam operasi perusahaan. Menurut Agus Sartono (2010:121): “Debt to Equity Ratio (DER) adalah total utang dibagi total modal sendiri yaitu dengan membandingkan antara total utang yang dimiliki perusahaan dengan modal sendiri." Atau dengan rumus:

$$
\text { DER }=\frac{\text { TOTAL HUTANG }}{\text { MODAL SENDIRI }}
$$

\section{Price Earning Ratio}

Menurut Mamduh M. Hanafi dan Abdul Halim (2012:83): "Price Earning Ratio (PER) melihat harga saham relatif terhadap earning-nya." PER bisa dihitung sebagai berikut:

$$
\begin{aligned}
& \text { PER }=\frac{\text { HARGA SAHAM }}{\text { EPS (EARNING PER SHARE) }} \\
& \text { Price Earning Ratio yang tinggi }
\end{aligned}
$$
menunjukkan bahwa investor bersedia untuk membayar dengan harga saham premium untuk perusahaan. Berdasarkan pendapat diatas pengertian Price Earning Ratio yang dimaksud dalam penelitian ini adalah rasio yang membandingkan antara harga saham per lembar saham biasa yang beredar dengan laba per lembar saham.

Perusahaan dengan peluang tingkat pertumbuhan tinggi biasanya mempunyai Price Earning Ratio yang tinggi pula, dan hal ini menunjukkan bahwa pasar mengharapkan pertumbuhan laba di masa mendatang. Sebaliknya perusahaan dengan tingkat pertumbuhan yang rendah cenderung mempunyai Price Earning Ratio yang rendah pula.

\section{Earning Per Share (EPS)}

Earning Per Share adalah keuntungan setelah dikurangi pajak pendapatan dengan cara membagi jumlah keuntungan yang tersedia untuk pemegang saham biasa dengan jumlah lembar saham biasa yang beredar. Menurut Darmaji (2001:139) EPS merupakan rasio yang menunjukan berapa besar keuntungan (return) yang diperoleh investor atau pemegang saham dari perlembar saham. Dengan rumus: 


$$
\text { EPS }=\frac{\text { LABA BERSIH }}{\text { JUMLAH SAHAM BEREDAR }}
$$

\section{METODE}

Populasi dalam penelitian ini berjumlah 5 tahun laporan keuangan (Dalam Data Panel) Perusahaan Rokok Yang Terdaftar Di Bursa Efek Indonesia Periode 2012-2016. Sampel dalam penelitian ini berjumlah 5 tahun laporan keuangan (Dalam Data Panel) Perusahaan Rokok Yang Terdaftar Di Bursa Efek Indonesia Periode 2012-2016. Jenis penelitian yang dipakai adalah kuantitatif, dimana tujuannya adalah untuk mengetahui pengaruh antara variabel bebas terhadap variabel terikat baik parsial maupun simultan Dalam menganalisis data digunakan uji instrumen, uji asumsi klasik, regresi, koefisien korelasi, koefisien determinasi dan uji hipotesis.

\section{HASIL DAN PEMBAHASAN}

\section{Analisis Deskriptif}

Pada pengujian ini digunakan untuk mengetahui skor minimum dan maksimum, mean score dan standar deviasi dari masing-masing variabel. Adapun hasilnya sebagai berikut:

Tabel 2. Hasil Analisis Descriptive Statistics

Descriptive Statistics

\begin{tabular}{lc|r|r|r|r} 
& N & Minimum & Maximum & Mean & Std. Deviation \\
\hline ROE (X1) & 20 & -1.63 & .76 & .0850 & .51579 \\
\hline DER (X2) & 20 & -8.34 & 9.47 & .4320 & 3.20067 \\
\hline PER (Y) & 20 & -12.99 & 40.41 & 15.4825 & 13.56529 \\
\hline Valid N (listwise) & 20 & & & & \\
\hline
\end{tabular}

Return On Equity Ratio diperoleh persentase minimum sebesar $-1,63 \%$ dan persentase maximum $0,76 \%$ dengan persentase rata-rata sebesar $0,085 \%$ dengan standar deviasi 0,515.

Debt Equity Ratio diperoleh persentase minimum sebesar -8,34 dan persentase maximum 0,76 dengan persentase ratarata sebesar $0,432 \%$ dengan standar deviasi 3,200.

Price Earning Ratio diperoleh nilai minimum sebesar $-12,99$ dan nilai maximum 40,41 dengan nilai rata-rata sebesar 15,482 dengan standar deviasi
13,565 .

\section{Analisis Verifikatif}

Pada analisis ini dimaksudkan untuk mengetahui pengaruh variabel independen terhadap variabel dependen. Adapun hasil pengujian sebagai berikut:

\section{a. Analisis Regresi Linier Berganda}

Uji regresi ini dimaksudkan untuk mengetahui perubahan variabel dependen jika variabel independen mengalami perubahan. Adapun hasil pengujiannya sebagai berikut:

Tabel 3. Hasil Pengujian Regresi Linier Berganda

\section{Coefficients ${ }^{\mathrm{a}}$}

Unstandardized Coefficients Standardized Coefficients

\begin{tabular}{|c|c|c|c|c|c|}
\hline Model & B & Std. Error & Beta & $\mathrm{t}$ & Sig. \\
\hline 1 (Constant) & 14.324 & 2.070 & & 6.918 & .000 \\
\hline ROE (X1) & 23.899 & 4.772 & .909 & 5.008 & .000 \\
\hline DER (X2) & -2.020 & .769 & -.477 & -2.627 & .018 \\
\hline
\end{tabular}

a. Dependent Variable: PER (Y)

Berdasarkan hasil pengujian pada tabel di atas, diperoleh persamaan regresi $\mathrm{Y}=14,324+23,699 \mathrm{X} 1$ 2,020X2. Dari persamaan tersebut dijelaskan sebagai berikut:

1) Konstanta sebesar 14,324 diartikan jika Return On Equity Ratio dan Debt Equity Ratio tidak ada, maka telah terdapat nilai Price Earning Ratio sebesar 14,324 point.

2) Koefisien regresi Return On Equity Ratio sebesar 23,699, angka ini positif artinya setiap ada peningkatan Return On Equity Ratio sebesar 23,699 maka Price Earning Ratio juga akan mengalami 
peningkatan sebesar 23,699 point.

3) Koefisien regresi Debt Equity Ratio sebesar -2,020, angka ini negatif artinya setiap ada perubahan Debt Equity Ratio sebesar -2,020 maka Price Earning Ratio akan mengalami penurunan sebesar -2,020 point.

\section{b. Analisis Koefisien Korelasi}

Analisis koefisien korelasi dimaksudkan untuk mengetahui tingkt kekuatan hubungan dari variabel independen terhadap variabel dependen baik secara parsial maupun simultan. Adapun hasil pengujian sebagai berikut:

Tabel 4. Hasil Pengujian Koefisien Korelasi

Return On Equity Ratio Terhadap Price Earning Ratio.

Correlations ${ }^{b}$

\begin{tabular}{llr|r} 
& & ROE (X1) & PER (Y) \\
\hline ROE & Pearson & 1 & $.657^{* *}$ \\
(X1) & Correlation & & \\
\cline { 2 - 4 } & Sig. (2-tailed) & & .002 \\
\hline PER & Pearson & $.657^{* *}$ & 1 \\
(Y) & Correlation & & \\
\cline { 2 - 4 } & Sig. (2-tailed) & .002 & \\
\hline
\end{tabular}

Tabel 6. Hasil Pengujian Koefisien Korelasi Return On Equity Ratio dan Debt Equity Ratio secara simultan Terhadap Price Earning Ratio.

\section{Model Summary}

\begin{tabular}{lc|c|c|c|} 
Model & R & R Square & Adjusted R Square & Std. Error of the Estimate \\
\hline 1 & $772^{a}$ &
\end{tabular}

a. Predictors: (Constant), DER (X2), ROE (X1)

Berdasarkan hasil pengujian diperoleh nilai korelasi sebesar 0,772 artinya Return On Equity Ratio dan Debt Equity Ratio secara simultan memiliki hubungan yang kuat terhadap Price Earning Ratio.
**. Correlation is significant at the 0.01 level (2tailed).

b. Listwise $\mathrm{N}=20$

Berdasarkan hasil pengujian diperoleh nilai korelasi sebesar 0,657 artinya Return On Equity Ratio memiliki hubungan yang kuat terhadap Price Earning Ratio.

Tabel 5. Hasil Pengujian Koefisien Korelasi

Debt Equity Ratio Terhadap Price Earning Ratio.

Correlations $^{\mathrm{a}}$

\begin{tabular}{llr|r} 
& & $\begin{array}{l}\text { DER } \\
\text { (X2) }\end{array}$ & PER (Y) \\
\hline $\begin{array}{llr}\text { DER } \\
\text { (X2) }\end{array}$ & Pearson & 1 & .003 \\
& Correlation & & \\
\cline { 2 - 3 } & Sig. (2-tailed) & & .991 \\
\hline PER (Y) & $\begin{array}{l}\text { Pearson } \\
\text { Correlation }\end{array}$ & .003 & 1 \\
\cline { 2 - 3 } & Sig. (2-tailed) & .991 & \\
\hline
\end{tabular}

a. Listwise $\mathrm{N}=20$

Berdasarkan hasil pengujian diperoleh nilai korelasi sebesar 0,003 artinya Debt Equity Ratio memiliki hubungan yang sangat lemah terhadap Price Earning Ratio. 
Price Earning Ratio.

Tabel 12. Hasil Uji Hipotesis Return On Equity Ratio dan Debt Equity Ratio Terhadap Price Earning Ratio.

ANOVAa

\begin{tabular}{lrr|r|r|c|c} 
Model & Sum of Squares & df & Mean Square & F & Sig. \\
\hline 1 Regression & 2083.961 & 2 & 1041.980 & 12.542 & $.000^{\mathrm{b}}$ \\
\hline Residual & 1412.364 & 17 & 83.080 & & \\
\hline Total & 3496.325 & 19 & & & \\
\hline
\end{tabular}

a. Dependent Variable: PER (Y)

b. Predictors: (Constant), DER (X2), ROE (X1)

Berdasarkan hasil pengujian pada tabel di atas, diperoleh nilai Signifikansi (Sig.) 0,000 < 0,05, dengan demikian hipotesis ketiga yang diajukan bahwa terdapat pengaruh yang signifikan atara Return On Equity Ratio dan Debt Equity Ratio terhadap Price Earning Ratio diterima.

\section{Pembahasan Hasil Penelitian}

\section{Pengaruh Return On Equity Ratio} Terhadap Price Earning Ratio

Return On Equity Ratio berpengaruh signifikan terhadap Price Earning Ratio dengan korelasi sebesar 0,657 atau memiliki hubungan yang kuat dengan kontribusi pengaruh sebesar 43,2\%. Pengujian hipotesis diperoleh nilai signifikansi (Sig.) 0,002<0,05. Dengan demikian hipotesis pertama yang diajukan bahwa terdapat berpengaruh signifikan antara Return On Equity Ratio terhadap Price Earning Ratio diterima.

\section{Pengaruh Debt Equity Ratio Terhadap Price Earning Ratio}

Debt Equity Ratio berpengaruh signifikan terhadap Price Earning Ratio dengan korelasi sebesar 0,003 atau memiliki hubungan yang kuat dengan kontribusi pengaruh sebesar 00,1\%. Pengujian hipotesis diperoleh nilai signifikansi (Sig.) 0,991 > 0,05. Dengan demikian hipotesis kedua yang diajukan bahwa terdapat berpengaruh signifikan antara Debt Equity Ratio terhadap Price Earning Ratio ditolak.

\section{Pengaruh Return On Equity Ratio dan Debt Equity Ratio Terhadap Price Earning Ratio \\ Return On Equity Ratio dan Debt} Equity Ratio berpengaruh signifikan terhadap Price Earning Ratio dengan diperoleh persamaan regresi $Y=14,324+$ $23,699 \mathrm{X} 1+-2,020 \mathrm{X} 2$, nilai korelasi sebesar 0,772 atau memiliki hubungan yang kuat dengan kontribusi pengaruh sebesar 59,6\% sedangkan sisanya sebesar $40,4 \%$ dipengaruhi faktor lain. Pengujian hipotesis diperoleh nilai Signifikansi (Sig.) $0,000<0,05$. Dengan demikian hipotesis ketiga yang diajukan bahwa terdapat berpengaruh signifikan antara Return On Equity Ratio dan Debt Equity Ratio terhadap Price Earning Ratio diterima.

\section{PENUTUP}

\section{Simpulan}

1. Return On Equity Ratio berpengaruh signifikan terhadap Price Earning Ratio dengan kontribusi pengaruh sebesar $43,2 \%$. Uji hipotesis diperoleh nilai signifikansi (Sig.) $0,002<0,05$..

2. Debt Equity Ratio tidak berpengaruh signifikan terhadap Price Earning Ratio dengan kontribusi pengaruh sebesar $00,1 \%$. Uji hipotesis diperoleh nilai signifikansi (Sig.) 0,991 >0,05..

3. Return On Equity Ratio dan Debt Equity Ratio berpengaruh signifikan terhadap Price Earning Ratio dengan kontribusi pengaruh sebesar 59,6\% sedangkan sisanya sebesar $40,4 \%$ dipengaruhi faktor lain. Uji hipotesis diperoleh nilai Signifikansi (Sig.) 0,000<0,05.

\section{Saran}

1. Bagi perusahaan yang ingin meningkatkan nilai perusahaannya dengan menggunakan tolak ukur Price Earning Ratio (PER), maka disarankan harus lebih memperhatikan faktor yang mempengaruhi rasio PER tersebut, yaitu Return On Equity dan Debt Equity Ratio karena secara parsial memiliki pengaruh 
signifikan terhadap Price Earning Ratio dalam penelitian ini.

2. Bagi peneliti selanjutnya disarankan untuk memperpanjang periode penelitian dan memperluas sampel perusahaan dengan mencangkup industri-industri pasar modal lainnya serta menambah variabel independennya sehingga dapat diperoleh gambaran lebih jelas mengenai faktor apa saja yang mempengaruhi Price Earning Ratio.

\section{DAFTAR PUSTAKA}

Agus Harjito \& Martono, (2010) "Manajemen Keuangan" Penerbit Ekonisia Yogyakarta.

Ayu Sri Mahatma Dewi dan Ary Wirajaya (2013), Pengaruh Struktur Modal, Profitabilitas Dan Ukuran Perusahaan Terhadap Nilai Perusahan E-Jurnal Akuntansi Universitas Udayana 4.2: 358-372

Azhar, susanto. (2007) "Sistem Informasi Manajemen", Lingga Jaya Bandung.

Bambang Riyanto, (2011). "Dasar-dasar Pembelanjaan Perusahaan". Edisi ke empat, BPFE Yogyakarta.

Dewi Ernawati dan Dini Widyawati (2015), Pengaruh Profitabilitas, Leverage dan Ukuran Perusahaan terhadap Nilai Perusahaan. Jurnal Ilmu \& Riset Akuntansi Vol. 4 No. 4

Fahmi, irham (2012), "Pengantar Manajemen Keuangan" Cetakan pertama penerbit Alfabeta, Bandung.

Fahmi, Irham, (2011) "Analisis Kinerja Keuagan Panduan bagi Akademisi, Manajer dan Investor Untuk Menilai dan Menganalisis Bisnis dari Aspek Keuangan" Alfabeta, Bandung.

Gunawan, Imam (2016), "Pengantar Statistika Inferensial" PT. Rajagrafindo Persada, Jakarta

Halim, J. (2005). Pengaruh likuididas, leverage, dan deviden terhadap Price Earning Ratio pada industri manufaktur di Bursa Efek Jakarta. Jurnal Akuntansi, Fakultas Ekonomi Universitas Katolik Indonesia Atmajaya. Jakarta.

Hanadelansa, H., \& Rawi, R. D. P. (2019). Analisis Audit Operasional Atas Pemberian Kredit Pemilikan Rumah Pada Pt Bank Rakyat Indonesia
(Persero) Tbk Kantor Cabang Panakukkang Di Kota Makassar. SENTRALISASI, 8(1), 33-42.

Hanafi, Mamduh M. (2004), Manajemen Keuangan. Yogyakarta: BPFE

Haque, M. G., Nurjaya, N., Affandi, A., Erlangga, H., \& Sunarsi, D. (2021). Micro Financial Sharia Non-bank Strategic Analysis: a Study at BMT Beringharjo, Yogyakarta. Budapest International Research and Critics Institute (BIRCI-Journal): Humanities and Social Sciences, 4(2), 1677-1686.

Jaka Pratama (2015), "Analisis factor fundamental perusahaan terhadap Price to Earning Ratio (PER) sebagai dasar penilaian saham perusahaan berbasis syariah yang tergabung dalam Jakarta Islamic Index (JII) Dibursa efek Indonesia (BEI) Periode 2009-2013 "Fakultas Ekonomi dan Bisnis, Jakarta Kasmir (2008), "Analisis Laporan keuangan", penerbit raja grafindo persada, Jakarta

Kasmir (2010), "Analisis Laporan keuangan", penerbit raja grafindo persada, Jakarta

Lutfi, A. M., Erlangga, H., Nurjaya, N., Priadana, S., \& Dwiwarman, D. A. (2021). Pengaruh Capital Adequacy Ratio Dan Bopo Ratio Terhadap Return On Asset Pada Pt. Bank Muamalat Indonesia, Tbk Periode 2010-2019. Jurnal Ekonomi Efektif, 3(3).

Munawir (2010), “Analisis Laporan Keuangan", Edisi Ke Empat, Penerbit Liberty, Yogyakarta.

Murtini, U. (2008). Pengaruh Kebijakan Manajemen Keuangan Terhadap Nilai Perusahaan. Jurnal Riset Akuntansi dan Keuangan.Vol. 4, No. 1, pp: 32-47.

Muslimat, A., Muhsin, H., Wahid, H. A., Yulistiana, I., Sunarsi, D., Dewi, K., ... \& Ilham, D. (2021). Develop Technology Based Multimedia For Indonesian Teachers. Journal of Contemporary Issues in Business and Government, 27(1), 1871-1882.

Purwanti, Y. (2021). The Influence Of Digital Marketing \& Innovasion On The School Performance. Turkish Journal of Computer and Mathematics Education (TURCOMAT), 12(7), 118-127.

Muslimat, A. (2021). Masa Depan Kampus Merdeka \& Merdeka Belajar: Sebuah 
Bunga Rampai Dosen. Bintang Visitama Publisher.

Nurjaya, N., Affandi, A., Ilham, D., Jasmani, J., \& Sunarsi, D. (2021). Pengaruh Kompetensi Sumber Daya Manusia Dan Kemampuan Pemanfaatan Teknologi Terhadap Kinerja Aparatur Desa Pada Kantor Kepala Desa Di Kabupaten Gunungkidul, Yogyakarta. JENIUS (Jurnal Ilmiah Manajemen Sumber Daya Manusia), 4(3), 332-346.

Najibullah, et al. (2021). Pengaruh non Performing Financing dan Financing to Deposit Ratio terhadap Pembiayaan pada Bank DKI Syariah. Jurnal Neraca Peradaban. Volume 1. Issue1. Pages 485

Ni Putu Yuria Mendra (2016), "Pengaruh Rasio Keuangan Terhadap Price Earing Ratio Pada Perusahaan Manufaktur yang terdaftar di Bursa Efek Indonesia Tahun 2012-2014" Universitas Mahasaraswati Denpasar,

Nurjaya, et al (2021). Pengaruh Liquiditas dan Profitabilitas terhadap Return Saham: Studi Empiris Pada Perusahaan Real Estate Dan Property Yang Terdaftar Di Bursa Efek Indonesia Tahun 2017-2019. Jurnal Tadbir Peradaban Volume 1. Issue.1. Pages 6068.

Pujiati, H., Sunarsi, D., Affandi, A., \& Anggraeni, N. (2021). Effect of ISO 9001: 2015 Quality Management
Implementation in Education on School Performance. Journal of Contemporary Issues in Business and Government, 27(1), 1848-1855.

Salam, A., Hikmat, I., Haquei, F., \& Badariah, E. (2021). The Influence of Share Ownership, Funding Decisions, Csr and Financial Performance of Food Industry. Annals of the Romanian Society for Cell Biology, 12698-12710.

Sartono, (2013) "manajemen keuangan teori konsep \& aplikasi" Yogyakarta EKONISIA,2013

Sugiono (2009), "Metode Penelitian Bisnis (Pendekatan Kuantitatif, Kualitatif, dan R\&D)", Penerbit Alfabeta, Bandung

Sugiono (2010), "Metode Penelitian Bisnis (Pendekatan Kuantitatif, Kualitatif, dan RND)", Penerbit Alfabeta, Bandung.

Sugiono (2013), "Statistika Penelitian", Penelitian Alfabeta, Bandung

Sugiyono, (2005) "Memahami Penelitian Kualitatif", Penerbit Alfabeta, Bandung.

Sunaryo (2011) Pengaruh Current Ratio, Debt To Equity Ratio, Dan Devidend Pay Out Ratio Terhadap Price Earning Ratio Pada Kelompok Perusahaan Manufaktur Yang Terdaftar di Bursa Efek Indonesia Binus Business Review Vol. 2 No. 2 : 866-873

V. Wiratna Sujarweni (2014), "Metodologi Penelitian", Cetakan pertama, penerbit Pustaka Baru Press, Yogyakarta. 